Article

\title{
Biochar Effect on Maize Yield and Soil Characteristics in Five Conservation Farming Sites in Zambia
}

Gerard Cornelissen ${ }^{1,2,3, *}$, Vegard Martinsen ${ }^{2}$, Victor Shitumbanuma ${ }^{4}$, Vanja Alling ${ }^{1}$, Gijs D. Breedveld ${ }^{1,5}$, David W. Rutherford ${ }^{6}$, Magnus Sparrevik ${ }^{1}$, Sarah E. Hale ${ }^{1}$, Alfred Obia ${ }^{2}$ and Jan Mulder ${ }^{2}$

1 Department of Environmental Engineering, Norwegian Geotechnical Institute (NGI), P.O. Box 3930 Ullevål Stadion, NO-0806 Oslo, Norway; E-Mails: va@ngi.no (A.V.); gbr@ngi.no (G.D.B.); msp@ngi.no (M.S.); sah@ngi.no (S.E.H.)

2 Department of Plant and Environmental Sciences (IPM), Norwegian University of Life Sciences, P.O. Box 5003, NO-1432 Ås, Norway; E-Mails: vegard.martinsen@umb.no (V.M.); alfred.obia@umb.no (A.O.); jan.mulder@umb.no (J.M.)

3 Department of Applied Environmental Sciences (ITM), Stockholm University, Stockholm, 10691 Sweden

4 Department of Soil Science, University of Zambia (UNZA), Lusaka, 10101 Zambia; E-Mail: vshitumbanuma@hotmail.com

5 Department of Geosciences, University of Oslo, 0316 Oslo, Norway

6 Water Resources Division, US Geological Survey, Denver, CO 80225, USA; E-Mail: dwruther@usgs.gov

* Author to whom correspondence should be addressed; E-Mail: gco@ngi.no; Tel.: +47-97724503; Fax: +47-22230448.

Received: 29 December 2012; in revised form: 1 March 2013 / Accepted: 7 April 2013 / Published: 11 April 2013

Abstract: Biochar addition to agricultural soils can improve soil fertility, with the added bonus of climate change mitigation through carbon sequestration. Conservation farming (CF) is precision farming, often combining minimum tillage, crop rotation and residue retention. In the present farmer-led field trials carried out in Zambia, the use of a low dosage biochar combined with CF minimum tillage was tested as a way to increase crop yields. Using CF minimum tillage allows the biochar to be applied to the area where most of the plant roots are present and mirrors the fertilizer application in CF practices. The CF practice used comprised manually hoe-dug planting 10-L sized basins, where $10 \%-12 \%$ of the land was tilled. Pilot trials were performed with maize cob biochar and wood biochar 
on five soils with variable physical/chemical characteristics. At a dosage as low as 4 tons/ha, both biochars had a strong positive effect on maize yields in the coarse white aeolian sand of Kaoma, West-Zambia, with yields of $444 \% \pm 114 \%(p=0.06)$ and $352 \% \pm 139 \%(p=0.1)$ of the fertilized reference plots for maize and wood biochar, respectively. Thus for sandy acidic soils, $\mathrm{CF}$ and biochar amendment can be a promising combination for increasing harvest yield. Moderate but non-significant effects on yields were observed for maize and wood biochar in a red sandy clay loam ultisol east of Lusaka, central Zambia (University of Zambia, UNZA, site) with growth of $142 \% \pm 42 \%(p>0.2)$ and $131 \% \pm 62 \%(p>0.2)$ of fertilized reference plots, respectively. For three other soils (acidic and neutral clay loams and silty clay with variable cation exchange capacity, CEC), no significant effects on maize yields were observed $(p>0.2)$. In laboratory trials, $5 \%$ of the two biochars were added to the soil samples in order to study the effect of the biochar on physical and chemical soil characteristics. The large increase in crop yield in Kaoma soil was tentatively explained by a combination of an increased base saturation (from $<50 \%$ to $60 \%-100 \%$ ) and cation exchange capacity (CEC; from $2-3$ to $5-9 \mathrm{cmol} / \mathrm{kg}$ ) and increased plant-available water (from $17 \%$ to $21 \%$ ) as well as water vapor uptake (70 mg/g on maize cob biochar at $50 \%$ relative humidity).

Keywords: biochar; conservation farming; crop yield; acidity; CEC; plant-available water

\section{Introduction}

The research field of biochar is expanding rapidly, mainly because of its potential for carbon sequestration [1], but also for its promise as a technology for immobilizing pollutants [2], handling waste [3] and increasing soil fertility [4,5].

Earlier research has attributed the effect of biochar on crop yield to increased CEC and associated nutrient retention [4,6-11], increased $\mathrm{pH}$ and base saturation $[9,11,12]$, increased available $\mathrm{P}[8,11,12]$, and increased plant-available water [4,13]. Kimetu et al. [14] found that increased CEC caused by biochar could explain some but not all of the observed yield effects. Soil biological parameters have also been demonstrated to be affected by the addition of biochar, however often as a side effect of chemical changes in the soil. For example, the release or sorption of organic molecules from biochar may in some cases be responsible for increases or decreases in abundance and activity of soil (micro)biota [15]. Biochar could especially influence mycorrhizal abundance and/or functioning, allowing improved uptake of nutrients by plants [16].

A recent meta-analysis showed plant-available water and $\mathrm{pH}$ increase along with nutrient retention increases as the most important factors explaining the effect of biochar addition on plant growth [5]. However, in many studies it was not completely clear what factor was decisive for the observed biochar effects, or lack thereof, on crop yield [7,9,14,17]. The mentioned meta-analysis by Jeffery et al. [5] showed that the effect of biochar on crop yield is variable, ranging from $-28 \%$ to $+39 \%$, with a grand mean of $+10 \%$. The greatest effect $(+39 \%)$ was seen at unrealistically high application rates of 100 tons/ha suggesting that alternative methods to achieve positive crop yield 
effects at lower application rates are necessary. A significant effect of biochar on the crop yield was seen for rice and sorghum planted in a highly weathered Brazilian ferralsol, where up to a factor of eight effect was observed in different treatments with and without compost additions [18]. However, in an extensive field study in rice systems, no effect of rice husk biochar was observed in fertile soils, whereas poor soils showed a 16\%-35\% increase in harvest [17]. Negative effects of biochar amendments were reported when ryegrass was grown in biochar amended plots using biochars prepared from biosolids [19,20]. These negative effects are possibly explained by the introduction of heavy metals and other contaminants in biochar [19,21,22].

Conservation farming (CF) is a general term used for various forms of precision agriculture [23-25]. Often the elements of minimum tillage, crop rotation and residue retention are included. In sub-Saharan Africa, minimum tillage is often carried out by constructing hoe basins (manual farming) or rip lines (animal draft practice). Until now, there have been no studies that integrated the use of biochar into the concept of conservation farming. However, the combination of biochar amendment with minimum-tillage CF could be a viable opportunity for reducing the amount of biochar needed during an application because the biochar itself is concentrated where most of the plant roots are found (i.e., in the plant basins or rip lines).

The aim of the present study was two-fold: i) carrying out biochar field pilot studies to test whether integration of biochar amendment in conservation farming (CF) can be a way to increase yields at low biochar dosages, and ii) understanding the mechanism of increased soil fertility, or the lack thereof, by coupling laboratory biochar amendment studies to field pilots at sites with widely variable soil characteristics. The most important difference between the tested version of CF and traditional land use is the use of manual minimum tillage methods, where $10 \%-12 \%$ of the area is tilled by hoe basins [24,26,27]. All trials except for a block trial at the University of Zambia (UNZA) farm were fully farmer-led. The present study was limited to chemical and physical responses of soil to biochar; biological factors were outside the scope of our investigation.

The main agricultural waste material in the Zambian CF context is maize cobs [25,26] and was therefore used to make the biochar. We used wood biochar as a comparison for its agronomic effectiveness, but do not advocate its implementation, as agricultural waste materials should be used for making biochar.

Our hypotheses were that biochar would work well in a CF context since the biochar is concentrated in the basins where plant roots are, and because amelioration of the soil physical and chemical characteristics would lead to an increase in crop yield in the presence of biochar, either directly, or indirectly through beneficial effects on soil microbes and/or mycorrhizae. This is, to our knowledge, the first publication where biochar amendment is combined with conservation farming. In addition, publications of farmer-led trials performed outside experimental farms are scarce, as well as studies comparing field trials for several geographically, chemically and physically variable soils.

\section{Materials and Methods}

Biochars. Two biochars from either maize cobs or mixed softwood from secondary forest were prepared using a local/traditional earth-mound kiln technology. Generation temperatures were around $400{ }^{\circ} \mathrm{C}$, as measured with a digital thermocouple. Pyrolysis time was seven days. Biochars were 
crushed to a coarse powder. For laboratory measurements, the biochars were dry-sieved over $2 \mathrm{~mm}$. For field trials, the biochars were used without further treatment.

Soils. An overview of the trial setup, including field trial coordinates, cropping history, fertilizer amounts, planting dates and harvesting dates are given in Table 1. The field sites had highly variable soil characteristics: Kaoma (Ferrallic Arenosols; infertile, coarse white sands of aeolian origin; Table 1), Lusaka and Shimabala (both Haplic Luvisols; moderate fertility and clay illuviation; texture clay loam and silty clay, respectively), Mkushi (Haplic Acrisol; highly leached, acidic sandy loams and clay illuviation) and the University of Zambia (UNZA) experimental farm (Ultisol; Typic kandisultalf; dominant clay mineral kaolinite followed by illite, developed from limestone; Figure S1). All plots were on flat terrain, and heterogeneity due to e.g., termite mounds, earlier residue burning and organic waste discarding was avoided.

Experimental design of field trials. Biochar amendment was done in combination with conservation farming (CF). This version of CF utilizes soil dry-season preparation (rainfall is unimodal in Zambia, with rains falling between November and April; for annual rainfall data per site see Table 1), minimum tillage methods (basin digging; 15,800 basins per ha of around $15 \times 20 \times 40 \mathrm{~cm}$ (10 L) each, or around $10 \%-12 \%$ of soil disturbance [25,27]), use of herbicides (see further), crop rotations with legumes, and precision fertilization to minimize soil disturbance and to maximize the utilization of nutrients added to the soil [23-25]. All trials except the one at University of Zambia (UNZA) farm (see below) were farmer-led, i.e., sowing and plot maintenance was done by the farmers. Only biochar amendment and harvesting was done by the research team.

Biochar dosage. In the present field trial, biochar dosages of 0.8 and 4 tons/ha were used. Because the biochar was concentrated in the planting basins (Figure S2), these dosages would roughly correspond to around 6 and 30 tons/ha in conventional farming encompassing an even distribution of biochar over the whole area (broadcasting). The biochar application rates corresponded to approximately 1 and $5 \%$ of biochar in the basins, which allowed the $5 \%$ dose to be compared to the laboratory tests (see below). Only the $5 \%$ biochar dose was used in laboratory tests in order to clearly observe differences in physicochemical soil properties between biochar amended and unamended soils.

Field trial layout. Sowing of maize (Zea Mays; seed from Maize Research Institute and Zamseed, Lusaka, Zambia; four seeds per basin) was done between 15 November and 19 December. For details on sowing and harvesting dates, see Table 1. Three weeks before planting, herbicides were applied using $5.1 \mathrm{~kg} / \mathrm{ha}$ glyphosate. Late-season weeds were treated one month before harvesting with $1.32 \mathrm{~kg} /$ ha atrazine (6-chloro-4- $N$-ethyl-2- $N$-propan-2-yl-1,3,5-triazine-2,4-diamine; Table 1). One round of hand-weeding was performed halfway the growth season if needed. Synthetic fertilizer was also added to the basins (NPKS 10:20:10:6 before planting, followed by urea top dressing applied six weeks after crop emergence; see below and Table 1). No lime was applied as it was not the intention to mask the $\mathrm{pH}$ effect of biochar amendment, and because lime is difficult to obtain for most Zambian farmers. After applying the biochar and the fertilizer to the basins, soil $(10 \mathrm{~L})$ was back-filled and mixed thoroughly with the biochar and fertilizer using a hoe. The total size of the farmer-led trials (all except UNZA farm which was $600 \mathrm{~m}^{2}$ ) was around $1000 \mathrm{~m}^{2}$ at each station (totaling around 3500 plants). Each treatment consisted of three 0.9-m spaced rows of $50 \mathrm{CF} 10$ - $\mathrm{L}$ planting basins as described above (around 500 plants; $150 \mathrm{~m}^{2}$ ) separated by one $0.9-\mathrm{m}$ wide control row of 50 planting basins (Figure S3). To simplify treatments at the farmers' sites, no blocks were established, however, 
we compensated for the lack of replication through the large size of the plots. Details specific to one or two sites are as follows:

UNZA farm. This was the only block trial, consisting of four $25 \mathrm{~m}^{2}$ blocks per treatment ( 25 basins) and biochar application rates of 1 and 5 tons/ha, respectively (not 0.8 and 4 tons/ha such as in the other trials). One cropping cycle was studied. Fertilizer dosage was $154 \mathrm{~kg} / \mathrm{ha} \mathrm{N}, 56 \mathrm{~kg} / \mathrm{ha} \mathrm{P}, 28 \mathrm{~kg} / \mathrm{ha} \mathrm{K}$, $16.8 \mathrm{~kg} \mathrm{~S}$.

Kaoma and Mkushi. Two cropping cycles were studied (Table 1). Statistical data analysis was done by treating each cropping cycle as a replicate. Biochar application rates were 0.8 and 4 tons/ha.

Fertilizer dosage was $77 \mathrm{~kg} / \mathrm{ha} \mathrm{N}, 28 \mathrm{~kg} / \mathrm{ha} \mathrm{P,} 14 \mathrm{~kg} / \mathrm{ha} \mathrm{K}, 8.4 \mathrm{~kg} \mathrm{~S}$.

Shimabala and Lusaka. One cropping cycle was studied (Table 1). Statistical data analysis could therefore not be done for these two sites. Biochar application rates were 0.8 and 4 tons/ha. Fertilizer dosage was $154 \mathrm{~kg} / \mathrm{ha} \mathrm{N}, 56 \mathrm{~kg} / \mathrm{ha} \mathrm{P,} 28 \mathrm{~kg} / \mathrm{ha} \mathrm{K}, 16.8 \mathrm{~kg} \mathrm{~S}$.

Yield data. Yield was measured for air-dried grains. Moisture content was $10 \%-15 \%$, as measured by drying overnight at $110{ }^{\circ} \mathrm{C}$, and not corrected for in the yield data reported. The uncertainty in moisture content led to errors of up to $5 \%$ in the absolute harvest data but not in the relative biochar $v s$. non-biochar comparisons. Another potential source of uncertainty could be caused by the lack of replication in the farmer-led trials. To reduce this uncertainty, individual trial fields (of $150 \mathrm{~m}^{2}$ ) were larger than the often-used replicated $25 \mathrm{~m}^{2}$ plots. The sample size to obtain yield data was also larger than usual trials; grains were sampled from basins 10 to 40 of the middle row (to avoid edge effects) of each 3 rows of a certain treatment (30 basins, usually around 100 plants) and pooled into one sample (Figure S3), and weighed. At UNZA farm (where a replicated block trial was performed), the grains from the 9 inner basins of a 25-basin block were pooled into one sample and weighed.

Statistical testing of effects of treatments or additions was done using a two-sided $t$-test at a $95 \%$ confidence interval.

Soil CEC and pH. In the laboratory, we tested the effect of the two biochars on CEC, pH, base saturation, available $\mathrm{Al}^{3+}$, and plant-available water using the same soils sampled from the field sites. In addition, this study was innovative as water vapor sorption of the biochars was measured using a microbalance method. These data are used to aid the understanding of the effect that biochar can have on the soil water balance. The laboratory results were used to tentatively interpret the crop yield observations in the field. Biological effects were considered outside the realm of the present study.

Fifteen soils samples ( $500 \mathrm{~g}$ ) were taken from $0-15 \mathrm{~cm}$ depth (mixed samples from planting basins) at each $1000 \mathrm{~m}^{2}$-field plot and pooled into three replicate samples. Soils were characterized for $\mathrm{pH}$ $\left(1: 2.5 \mathrm{v} / \mathrm{v}\right.$; in $\mathrm{H}_{2} \mathrm{O}$ and $\left.0.01 \mathrm{M} \mathrm{CaCl}_{2}\right)$ and extracted with $1 \mathrm{M}$ ammonium acetate (adjusted to $\left.\mathrm{pH} 7\right)$ or $1 \mathrm{M}$ ammonium nitrate (unbuffered) to determine exchangeable base cations $\left(\mathrm{Ca}^{2+}, \mathrm{Mg}^{2+}, \mathrm{Na}^{+}, \mathrm{K}^{+}\right)$in the extracts. Extractable acidity was determined by back-titration with sodium hydroxide to $\mathrm{pH}$ 7. The sum of exchangeable base cations and acidity was used to determine cation exchange capacity (CEC). In addition, exchangeable $\mathrm{Al}^{3+}, \mathrm{Fe}^{2 / 3+}\left(\mathrm{NH}_{4} \mathrm{NO}_{3}\right.$ only) and $\mathrm{Mn}^{2+}$ were determined, as well as organic $\mathrm{C}$ (OC), $\mathrm{H}$ and $\mathrm{N}$ (catalytic combustion elemental analysis at $1030{ }^{\circ} \mathrm{C}$ after acidification with $50 \mu \mathrm{L} 1 \mathrm{M}$ $\mathrm{HCl}$ per $15 \mathrm{mg}$ dry sample). $\mathrm{pH}(1: 2.5 \mathrm{v} / \mathrm{v}), \mathrm{CEC}$ and $\mathrm{OC}, \mathrm{H}$, and $\mathrm{N}$ contents were determined for soils without and with 5\% biochar amendment (both wood and maize cob biochar mixed into the soil in the laboratory). Along with each CEC determination, five acidic internal reference soils were tested for consistency. The CEC determinations for these soils were always within $5 \%$ of the certified values. 
Table 1. Overview of field trials.

\begin{tabular}{|c|c|c|c|c|c|}
\hline & Kaoma & UNZA & Mkushi & Lusaka & Shimabala \\
\hline GPS & S 1449.571' & S $15^{\circ} 24.798^{\prime}$ & S 13॰36.361' & S 1522.712' & S 15 $39.278^{\prime}$ \\
\hline coordinates & E $24^{\circ} 52.970^{\prime}$ & E $28^{\circ} 42.166^{\prime}$ & E $29^{\circ} 22.681^{\prime}$ & E $28^{\circ} 22.269^{\prime}$ & E $28^{\circ} 14.503$ \\
\hline Soil type & Aeolian sand & Red oxisol & Weathered grey loam & Clay loam & Clay loam \\
\hline Type of trial & Farmer-led & $\begin{array}{l}\text { Block trial at experimental } \\
\text { farm, } 4 \text { replicates }\end{array}$ & Farmer-led & Farmer-led & Farmer-led \\
\hline Total size of & $1000 \mathrm{~m}^{2}$ & $500 \mathrm{~m}^{2}$ & $1000 \mathrm{~m}^{2}$ & $1000 \mathrm{~m}^{2}$ & $1000 \mathrm{~m}^{2}$ \\
\hline trial & 850 basins & 425 basins & 850 basins & 850 basins & 850 basins \\
\hline Crop & Maize & Maize & Maize & Maize & Maize \\
\hline Treatments & $\begin{array}{l}\text { Non-fertilized control } \\
\text { Fertilized control } \\
0.8 \text { ton/ha wood biochar } \\
4 \text { ton/ha wood biochar } \\
0.8 \text { ton/ha cob biochar } \\
4 \text { ton/ha cob biochar }\end{array}$ & $\begin{array}{l}\text { Non-fertilized control } \\
\text { Fertilized control } \\
1 \text { ton/ha wood biochar } \\
5 \text { ton/ha wood biochar } \\
5 \text { ton/ha cob biochar }\end{array}$ & $\begin{array}{c}\text { Fertilized control } \\
0.8 \text { ton/ha wood biochar } \\
4 \text { ton/ha wood biochar } \\
0.8 \text { ton/ha cob biochar } \\
4 \text { ton/ha cob biochar }\end{array}$ & $\begin{array}{c}\text { Fertilized control } \\
0.8 \text { ton/ha wood biochar } \\
4 \text { ton/ha wood biochar } \\
0.8 \text { ton/ha cob biochar } \\
4 \text { ton/ha cob biochar }\end{array}$ & $\begin{array}{c}\text { Fertilized control } \\
0.8 \text { ton/ha wood biochar } \\
4 \text { ton/ha wood biochar } \\
0.8 \text { ton/ha cob biochar } \\
4 \text { ton/ha cob biochar }\end{array}$ \\
\hline $\begin{array}{c}\text { Planting } \\
\text { date(s) }\end{array}$ & $\begin{array}{l}19-11-2010(\text { season } 1) \\
23-11-2011(\text { season } 2)\end{array}$ & $18-12-2010$ & $\begin{array}{l}26-11-2010(\text { season } 1) \\
21-11-2011(\text { season } 2)\end{array}$ & $19-11-2010$ & $16-11-2010$ \\
\hline $\begin{array}{l}\text { Harvesting } \\
\text { date(s) }\end{array}$ & $\begin{array}{l}15-4-2011(\text { season } 1) \\
20-4-2012(\text { season } 2)\end{array}$ & $15-5-2011$ & $\begin{array}{l}3-5-2011(\text { season } 1) \\
10-5-2012(\text { season } 2)\end{array}$ & $15-4-2011$ & $15-4-2011$ \\
\hline Fertilizer & $\begin{array}{c}77 \mathrm{~kg} / \mathrm{ha} \mathrm{N} \\
\left(\mathrm{NH}_{4} \mathrm{NO}_{3} \text { and urea), }\right. \\
28 \mathrm{~kg} / \mathrm{ha} \mathrm{P}, 8.4 \mathrm{~kg} \mathrm{~S} \\
\text { (Single Superphosphate), } \\
14 \mathrm{~kg} / \mathrm{ha} \mathrm{K}\left(\mathrm{K}_{2} \mathrm{O}\right)\end{array}$ & $\begin{array}{c}154 \mathrm{~kg} / \mathrm{ha} \mathrm{N} \\
\left(\mathrm{NH}_{4} \mathrm{NO}_{3} \text { and urea), }\right. \\
56 \mathrm{~kg} / \mathrm{ha} \mathrm{P}, 16.8 \mathrm{~kg} \mathrm{~S} \\
\text { (Single Superphosphate), } \\
28 \mathrm{~kg} / \mathrm{ha} \mathrm{K}\left(\mathrm{K}_{2} \mathrm{O}\right)\end{array}$ & $\begin{array}{c}77 \mathrm{~kg} / \mathrm{ha} \mathrm{N} \\
\left(\mathrm{NH}_{4} \mathrm{NO}_{3} \text { and urea }\right), \\
28 \mathrm{~kg} / \mathrm{ha} \mathrm{P}, 8.4 \mathrm{~kg} \mathrm{~S} \\
\text { (Single Superphosphate), } \\
14 \mathrm{~kg} / \mathrm{ha} \mathrm{K}\left(\mathrm{K}_{2} \mathrm{O}\right)\end{array}$ & $\begin{array}{c}154 \mathrm{~kg} / \mathrm{ha} \mathrm{N} \\
\left(\mathrm{NH}_{4} \mathrm{NO}_{3} \text { and urea), }\right. \\
56 \mathrm{~kg} / \mathrm{ha} \mathrm{P}, 16.8 \mathrm{~kg} \mathrm{~S} \\
\text { (Single Superphosphate), } \\
28 \mathrm{~kg} / \mathrm{ha} \mathrm{K}\left(\mathrm{K}_{2} \mathrm{O}\right)\end{array}$ & $\begin{array}{c}154 \mathrm{~kg} / \mathrm{ha} \mathrm{N} \\
\left(\mathrm{NH}_{4} \mathrm{NO}_{3} \text { and urea), }\right. \\
56 \mathrm{~kg} / \mathrm{ha} \mathrm{P}, 16.8 \mathrm{~kg} \mathrm{~S} \\
\text { (Single Superphosphate), } \\
28 \mathrm{~kg} / \mathrm{ha} \mathrm{K}\left(\mathrm{K}_{2} \mathrm{O}\right)\end{array}$ \\
\hline Herbicides & $\begin{array}{c}5.1 \mathrm{~kg} \text { glyphosate } \\
1.32 \mathrm{~kg} \text { atrazine }\end{array}$ & $\begin{array}{c}5.1 \mathrm{~kg} \text { glyphosate } \\
1.32 \mathrm{~kg} \text { atrazine }\end{array}$ & $\begin{array}{c}5.1 \mathrm{~kg} \text { glyphosate } \\
1.32 \mathrm{~kg} \text { atrazine }\end{array}$ & $\begin{array}{l}5.1 \mathrm{~kg} \text { glyphosate } \\
1.32 \mathrm{~kg} \text { atrazine }\end{array}$ & $\begin{array}{c}5.1 \mathrm{~kg} \text { glyphosate } \\
1.32 \mathrm{~kg} \text { atrazine }\end{array}$ \\
\hline $\begin{array}{l}\text { Previous } \\
\text { season crop }\end{array}$ & Newly opened plot & Newly opened plot & Newly opened plot & Maize & Groundnuts \\
\hline $\begin{array}{c}\text { Annual } \\
\text { Rainfall (mm) }\end{array}$ & 930 & 940 & 1220 & 940 & 850 \\
\hline
\end{tabular}


Plant-available water. Soils (triplicate samples for 3 out of 5 soils (Kaoma, Lusaka, Shimabala), due to budgetary constraints) with and without 5\% maize cob biochar (mixed into the soils in the laboratory) were analyzed for soil moisture retention capacity, where soils were first saturated with water, allowed to drain, and thereafter exposed to increasing pressures to construct pF-curves [28]. Plant-available water was defined as the available water between $\mathrm{pF}=2$ (field capacity, below which water will freely drain) and $\mathrm{pF}=4.2$ (permanent wilting point where the remaining water is so tightly bound that it can no longer be taken up by plant roots). The dry weight (corrected for amount of roots and gravels and dried at $105{ }^{\circ} \mathrm{C}$ ) was used to determine bulk density $\left(\rho_{\mathrm{b}} ; \mathrm{g} \mathrm{cm}^{-3}\right)$ and particle density $\left(\rho_{\mathrm{s}} ; \mathrm{g} \mathrm{cm}^{-3}\right)$.

Water vapor sorption. This parameter was determined for both biochars as well as for uncharred feedstock (maize cobs) and pure cellulose, the main constituent of the feedstocks (wood and maize cobs). These measurements were done in order to determine the ability of the biochars to hold water vapor during dry spells. The measurements were done by equilibrating 100 to $120 \mathrm{mg}$ of sample at a fixed partial pressure of water vapor, at room temperature, in a sealed chamber, until equilibration was reached as indicated by the sample reaching a constant weight.

The vapor sorption apparatus consisted of a sealed chamber containing an electrical microbalance (Figure S4 in the Supplementary Information). The chamber was connected to a vacuum system so that the system, containing the test sample hanging from the microbalance in a small glass cup, could be evacuated to approximately $0.015 \mathrm{~Pa}$. The biochar samples were heated to $100{ }^{\circ} \mathrm{C}$ under vacuum to remove moisture and determine the dry sample weight.

The test liquid, water, was prepared by vacuum distillation to remove residual air and then was introduced into the chamber at set intervals for equilibration with the sorbent sample. A change of weight resulting from vapor uptake was recorded from the microbalance along with the pressure inside the chamber, and the room temperature. The sample was equilibrated until constant weight was reached, which required approximately $24 \mathrm{~h}$. The relative pressure of water was determined using the saturation vapor pressure of water at the temperature of the room at the time of the reading. This reduced variation in uptake due to minor temperature fluctuations in the laboratory.

\section{Results}

Field trials. Maize yields of the non-biochar-amended fertilized control plots varied from $<1$ to 9 tons/ha (Table 2). Biochar was observed to have the greatest effect on yield at the locations with lowest control yields, especially the sandy, acidic soils of Kaoma, where grain yields increased significantly from $0.9 \pm 0.1$ ton/ha without biochar to $3.8 \pm 0.5$ tons/ha with maize biochar ( $p=0.06$ for yield results averaged for the two cropping seasons) and $3.0 \pm 0.8$ tons/ha with wood biochar ( $p=0.1$ ), applied at a 4 ton/ha biochar dosage (Table 2). These yields were $444 \% \pm 114 \%$ and $352 \% \pm 139 \%$ of control yields, respectively (Tables 2 and S1; Figures 1 and S5). At a biochar dosage of 0.8 tons/ha in Kaoma, yields were $131 \% \pm 9 \%(p=0.08)$ and $134 \% \pm 22 \%(p=0.1)$ of the control yield for maize biochar and wood biochar, respectively. Photographs of the sites in Kaoma (strong effect of biochar) and Lusaka (no effect of biochar) can be found in Figures S6 and S7. The strong effect of the biochars in the Kaoma soil was sustained during the second growth season (2012), even though the relative effectiveness was reduced (Table S1; Figure S5). 
Table 2. Maize grain yields (tons/ha) for the five sites, without biochar and without fertilizer ("non-fertilized control"), without biochar but fertilized ("fertilized control"), and fertilized plus biochar-amended. Individual numbers for seasons 2011 and 2012 for Kaoma and Mkushi can be found in Table S1. Standard deviations are given either for two cropping seasons (Kaoma and Mkushi) or for four replicate blocks (UNZA), as indicated. For Lusaka and Shimabala, no replication was done.

\begin{tabular}{cccccc}
\hline & Kaoma $^{\text {a }}$ & UNZA $^{\text {b }}$ & Mkushi $^{\text {a }}$ & Lusaka $^{\mathbf{c}}$ & Shimabala $^{\mathbf{c}}$ \\
\hline Non-fertilized control & $0.5 \pm 0.1$ & $1.8 \pm 1.2$ & n.a. $^{\mathrm{d}}$ & n.a. $^{\mathrm{d}}$ & n.a. $^{\mathrm{d}}$ \\
Fertilized control & $0.9 \pm 0.1$ & $2.6 \pm 1.2$ & $5.3 \pm 0.7$ & 9.1 & 8.6 \\
Maize cob biochar 0.8 t/ha & $1.2 \pm 0.2$ & n.a. $^{\mathrm{d}}$ & $5.3 \pm 1.5$ & 9.0 & 11.0 \\
Maize cob biochar 4 t/ha & $3.8 \pm 0.5$ & $3.7 \pm 1.1^{\mathrm{e}}$ & $4.2 \pm 0.9$ & 8.2 & 6.7 \\
Wood biochar 0.8 t/ha & $1.2 \pm 0.1$ & $2.8 \pm 1.4^{\mathrm{f}}$ & $5.2 \pm 0.9$ & 6.8 & 8.1 \\
Wood biochar 4 t/ha & $3.0 \pm 0.8$ & $3.4 \pm 1.6^{\mathrm{f}}$ & $6.0 \pm 0.6$ & 6.9 & 8.1 \\
\hline
\end{tabular}

${ }^{\mathrm{a}}$ average and standard deviation for two growth cycles (2010-2011 and 2011-2012); ${ }^{\mathrm{b}}$ average and standard deviation for four blocks in 2010-2011 season; ${ }^{\mathrm{c}}$ value for one block in 2010-2011 season; ${ }^{\mathrm{d}}$ n.a., not applicable since this treatment was not done at this location; ${ }^{\mathrm{e}}$ application rate 5 tons/ha.; ${ }^{\mathrm{f}}$ application rate 1 ton/ha.

Figure 1. Change in grain yield as a percentage of the fertilized control yield at each site (absolute yield numbers are in Table 2). A change of 100\% thus implies a doubling of harvest yield. Error bars in Kaoma and Mkushi represent standard deviations of average measurements for the seasons 2010-2011 and 2011-2012. Error bars for UNZA represent standard deviations in four blocks in season 2010-2011. No replicates for Shimabala and Lusaka were carried out. Individual numbers for seasons 2011 and 2012 for Kaoma and Mkushi can be found in Figure S7. ** significance $p<0.05$; ${ }^{*}$ significance $p<0.10$.

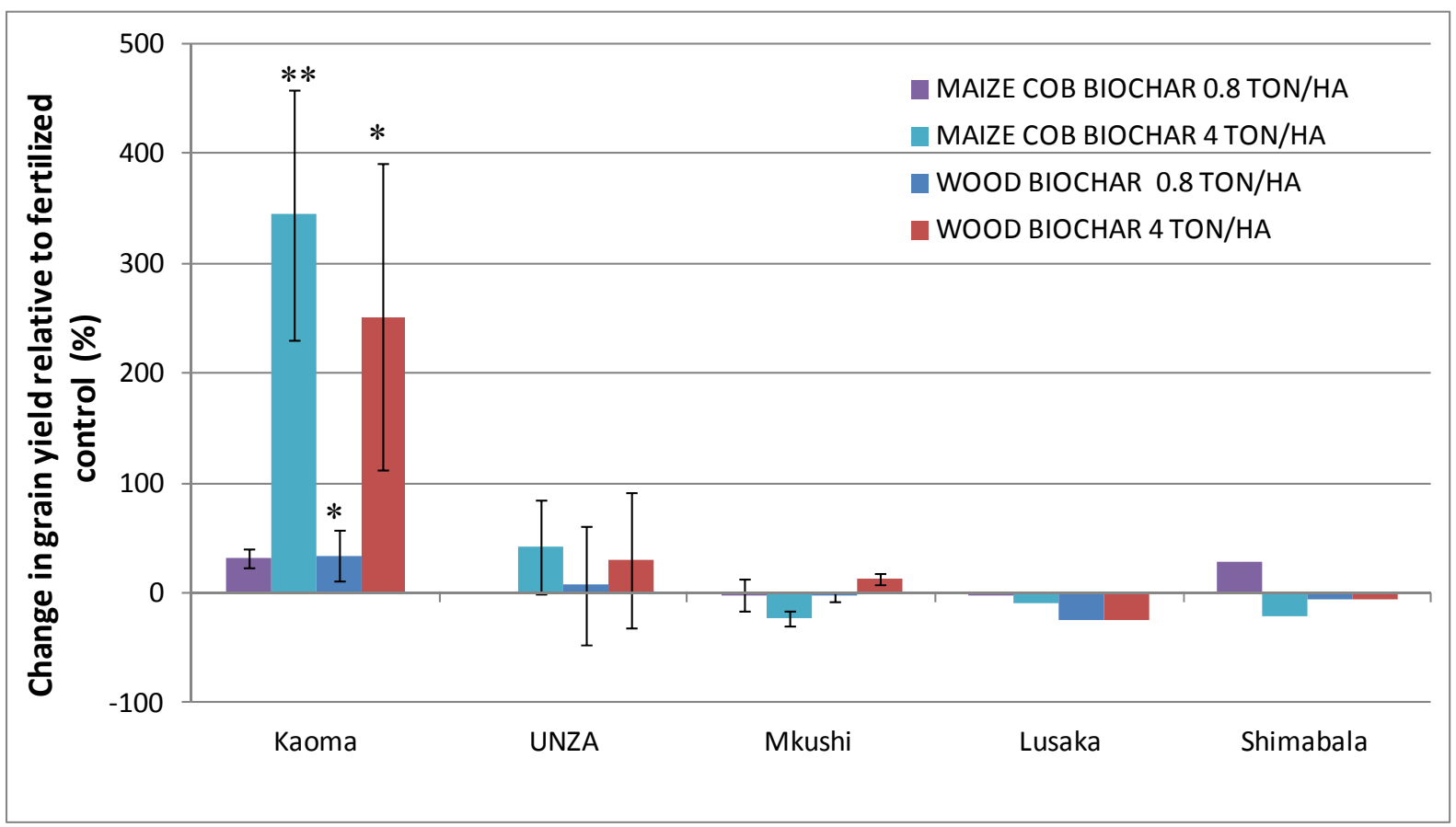


Biochar did not have a significant effect on grain yield at the UNZA farm $(p>0.2)$, with yields of $142 \% \pm 42 \%$ and $131 \% \pm 62 \%$ of the control plot yields at 4 ton/ha maize cob biochar and wood biochar amendment, respectively. No significant effect of biochar on crop yield was observed at the other sites (Mkushi, Shimabala, Lusaka), or at the UNZA site at 1 ton/ha (Figure $1 ; p>0.2$ ).

pH and CEC of soils, biochars and soil/biochar mixtures. All soils except the one from Lusaka were acidic, where the UNZA farm soil showed the strongest acidity, having a $\mathrm{pH}\left(\mathrm{CaCl}_{2}\right)$ of 4.1 (Table 3). The biochars were alkaline ( $\mathrm{pH}$ around 8; Table 3). Moisture contents were $2.72 \pm 0.02 \%$ and $4.60 \pm 0.03 \%$, respectively. Cation Exchange Capacities (CEC) were low for Mkushi, Kaoma and UNZA soils $\left[<4 \mathrm{cmol} / \mathrm{kg}\left(\mathrm{NH}_{4} \mathrm{NO}_{3}-\mathrm{CEC}\right) ;<9 \mathrm{cmol} / \mathrm{kg}\left(\mathrm{NH}_{4} \mathrm{Ac}-\mathrm{CEC}\right)\right]$, and moderate for Lusaka and Shimabala soils ( $>15 \mathrm{cmol} / \mathrm{kg}$ ). The Organic Carbon (OC) contents of the soils were below 1\%, except for the Shimabala soil (1.8\%). OC/N ratios were similar for soils and biochar (between 40 and 80), with the exception of the relatively fertile soils at Lusaka and Shimabala $(\mathrm{C} / \mathrm{N}$ for these soils $<20)$. The high $\mathrm{OC} / \mathrm{N}$ ratios of the biochars are probably explained by the high $\mathrm{OC} / \mathrm{N}$ ratios of the feedstock (softwood and maize cobs).

The biochars exhibited higher CEC values than the soils (40 and $85 \mathrm{cmol} / \mathrm{kg}$ for the maize cob biochar and the wood biochar, respectively). Washing the biochars with $10 \mathrm{~mL} / \mathrm{g}$ of deionized water led to reductions in biochar CEC (maximally 20\% reduction), indicating that part of the biochar CEC was associated with the soluble ash components.

The $\mathrm{pH}$ of all the acidic soils (Kaoma, Mkushi, UNZA, Shimabala) was substantially increased (from 4-6 to 6-7) by a 5\% addition of both biochars (Table 4). Wood biochar was more effective than maize cob biochar for soil $\mathrm{pH}$ neutralization, probably because of its higher CEC. The soil CEC was increased relatively most strongly (by 30\%-100\%; Table 4) for the low-CEC soils from Mkushi, UNZA and Kaoma by the addition of 5\% biochar, although increases were also observed for the less weathered soils from Lusaka and Shimabala (10\%-20\% increase; Table 4).

The acidic soils (Kaoma, UNZA, Mkushi) were observed to have a low base saturation (36\%-60\% with $\mathrm{NH}_{4} \mathrm{NO}_{3}$ extraction; $17 \%-45 \%$ with $\mathrm{NH}_{4} \mathrm{Ac}$ extraction). Amendment with $5 \%$ wood biochar to these soils resulted in base saturations of nearly $100 \%$ (Table 4), whereas amendment with maize cob biochar increased base saturations to a lesser extent, to $56 \%-82 \%\left(\mathrm{NH}_{4} \mathrm{NO}_{3}\right.$ extraction) and $28 \%-64 \%$ $\left(\mathrm{NH}_{4} \mathrm{Ac}\right.$ extraction). Thus, the higher-CEC wood biochar (CEC around $80 \mathrm{cmol} / \mathrm{kg}$ ) was more effective at restoring base saturation than the lower-CEC maize cob biochar $(40 \mathrm{cmol} / \mathrm{kg})$, due to its higher reserve alkalinity.

Along with increasing base saturation, the available $\mathrm{Al}^{3+}$ was reduced by the addition of $5 \%$ biochar: from 0.14 to $0.01 \mathrm{cmolc} / \mathrm{kg}$ (Kaoma), from 1.14 to $0.70 \mathrm{cmolc} / \mathrm{kg}$ (UNZA soil; maize cob char) and $0.02 \mathrm{cmolc} / \mathrm{kg}$ (UNZA soil; wood biochar), and from 0.18 to $0.01-0.06 \mathrm{cmolc} / \mathrm{kg}$ (Mkushi). Note that the available $\mathrm{Al}^{3+}$ was low in the Kaoma soil without biochar $(0.14 \mathrm{cmolc} / \mathrm{kg}) . \mathrm{Ca}^{2+}: \mathrm{Al}^{3+}$ ratios in the unamended soils were $\sim 1$ for UNZA soil (Table S2), and $>1$ for the other soils (around four for Kaoma and Mkushi; $>100$ for Shimabala and Lusaka). Biochar amendment improved the $\mathrm{Ca}^{2+}: \mathrm{Al}^{3+}$ ratio for the UNZA soil to values around 4. 
Table 3. Soil characteristics of the five field sites $(0-15 \mathrm{~cm}$ depth) and the two biochars (washed and unwashed). n.d, not determined.

\begin{tabular}{|c|c|c|c|c|c|c|c|c|c|c|c|}
\hline Location & $\begin{array}{c}\mathbf{p H} \\
\left(\mathrm{H}_{2} \mathrm{O}\right)\end{array}$ & $\begin{array}{c}\mathbf{p H} \\
\left(\mathrm{CaCl}_{2}\right)\end{array}$ & $\begin{array}{c}\mathrm{CEC}(\mathrm{cmol} / \mathrm{kg}) \\
\left(\mathrm{NH}_{4} \mathrm{NO}_{3}\right)\end{array}$ & $\begin{array}{c}\text { Base } \\
\text { sat. } \\
(\%)\end{array}$ & $\begin{array}{c}\mathrm{Al}^{3+} \\
(\mathrm{cmol} / \mathrm{kg})\end{array}$ & $\begin{array}{c}\mathrm{CEC}(\mathrm{cmol} / \mathrm{kg}) \\
\left(\mathrm{NH}_{4} \mathrm{Ac}\right)\end{array}$ & $\begin{array}{c}\text { Base } \\
\text { sat. } \\
(\%) \\
\end{array}$ & $\begin{array}{l}\text { OC } \\
(\%)\end{array}$ & $\begin{array}{c}\mathbf{H} \\
(\%)\end{array}$ & $\begin{array}{c}N \\
(\%)\end{array}$ & $\mathbf{O C} / \mathbf{N}$ \\
\hline Kaoma & $5.6 \pm 0.1^{\mathrm{b}}$ & $4.6 \pm 0.1$ & $2.2 \pm 2.1$ & $60 \pm 4$ & $\begin{array}{c}0.14 \pm \\
0.04\end{array}$ & $4.3 \pm 0.1$ & $45 \pm 2$ & $0.34 \pm 0.02$ & $0.04 \pm 0.01$ & $<0.01$ & $>34^{\mathrm{a}}$ \\
\hline UNZA & $4.8^{c}$ & 4.1 & 3.5 & 50 & 1.14 & 9.1 & 17 & 0.8 & 0.2 & 0.02 & $48^{\mathrm{a}}$ \\
\hline Mkushi & $6.5^{\mathrm{c}}$ & 5.2 & 3.4 & 36 & 0.18 & 3.1 & 39 & 0.4 & 0.10 & $<0.01$ & $>40^{\mathrm{a}}$ \\
\hline Lusaka & $7.9 \pm 0.1^{b}$ & $7.3 \pm 0.1$ & $17.3 \pm 0.1$ & 100 & $<0.001$ & $16.6 \pm 0.5$ & 100 & $0.87 \pm 0.01$ & $0.52 \pm 0.02$ & 0.03 & 29 \\
\hline Shimabala & $5.9 \pm 0.1^{b}$ & $5.6 \pm 0.1$ & $21.5 \pm 0.2$ & 100 & 0.002 & $26.2 \pm 1.1$ & 100 & $1.61 \pm 0.01$ & $0.82 \pm 0.04$ & 0.09 & 19 \\
\hline Wood biochar unwashed & $8.3^{c}$ & 7.9 & 77.9 & 100 & $<0.001$ & 86.0 & 100 & 64 & 2 & 0.8 & 83 \\
\hline Wood biochar washed & & & 75.6 & 100 & $<0.001$ & 82.5 & 100 & 60 & 1.4 & 0.7 & 86 \\
\hline $\begin{array}{c}\text { Maize cob biochar } \\
\text { unwashed }\end{array}$ & $8.0^{\mathrm{c}}$ & 7.1 & 34.1 & 100 & $<0.001$ & 39.9 & 88 & 74 & 3 & 0.9 & 87 \\
\hline Maize cob biochar washed & & & 22.6 & 96 & $<0.001$ & 27.9 & 78 & 74.7 & 3.1 & 0.8 & 92 \\
\hline Location & $\begin{array}{c}\text { Sand } \\
(\%)\end{array}$ & & $\begin{array}{l}\text { Silt } \\
(\%)\end{array}$ & \multicolumn{2}{|c|}{$\begin{array}{l}\text { Clay } \\
(\%)\end{array}$} & \multicolumn{2}{|l|}{ Texture class } & \multicolumn{2}{|c|}{$\begin{array}{l}\text { Bulk density } \rho_{\mathrm{b}} \\
\left(\mathrm{g} / \mathrm{cm}^{3}\right)\end{array}$} & \multicolumn{2}{|c|}{$\begin{array}{l}\text { article density } \rho_{\mathrm{s}} \\
\qquad\left(\mathrm{g} / \mathrm{cm}^{3}\right)\end{array}$} \\
\hline Kaoma & $87.9 \pm 0.4^{\mathrm{d}}$ & & $7.9 \pm 0.7$ & \multicolumn{2}{|c|}{$4.2 \pm 0.3$} & \multicolumn{2}{|l|}{ Sand } & \multicolumn{2}{|c|}{$1.43 \pm 0.09$} & \multicolumn{2}{|c|}{$2.52 \pm 0.05$} \\
\hline UNZA & $60.7^{\mathrm{c}}$ & & 17.6 & \multicolumn{2}{|c|}{21.7} & \multicolumn{2}{|l|}{ Sandy clay loam } & n.d. ${ }^{\mathrm{e}}$ & & \multicolumn{2}{|c|}{ n.d. } \\
\hline Mkushi & $62.5 \pm 0.4$ & & $25.4 \pm 0.3$ & \multicolumn{2}{|c|}{$12.2 \pm 0.1$} & \multicolumn{2}{|l|}{ Sandy loam } & $1.26 \pm 0.07$ & & \multicolumn{2}{|c|}{$2.50 \pm 0.04$} \\
\hline Lusaka & $30.3 \pm 0.1$ & & $42.6 \pm 0.1$ & \multicolumn{2}{|c|}{$27.2 \pm 0.1$} & \multicolumn{2}{|l|}{ Clay loam } & n.d. & & \multicolumn{2}{|c|}{ n.d. } \\
\hline Shimabala & $12.8 \pm 0.5$ & & $41.1 \pm 0.1$ & \multicolumn{2}{|c|}{$46.2 \pm 0.5$} & \multicolumn{2}{|l|}{ Silty clay } & $1.34 \pm 0.04$ & & \multicolumn{2}{|c|}{$2.53 \pm 0.01$} \\
\hline
\end{tabular}


Table 4. Chemical characteristics of soils with $5 \%$ biochar and controls with no biochar for both samples taken in the field and samples mixed with the biochar in the laboratory.

\begin{tabular}{|c|c|c|c|c|c|c|c|c|c|c|c|}
\hline Location & & $\begin{array}{c}\mathrm{pH} \\
\left(\mathrm{H}_{2} \mathrm{O}\right)\end{array}$ & $\begin{array}{c}\mathrm{pH} \\
\left(\mathrm{CaCl}_{2}\right)\end{array}$ & $\begin{array}{c}\mathrm{CEC}(\mathrm{cmol} / \mathrm{kg}) \\
\left(\mathrm{NH}_{4} \mathrm{NO}_{3}\right)\end{array}$ & $\begin{array}{c}\text { Base sat. } \\
(\%)\end{array}$ & $\begin{array}{c}\mathrm{Al}^{3+} \\
\left(\mathrm{cmol}^{3+} \mathrm{kg}\right)\end{array}$ & $\begin{array}{c}\mathrm{CEC}(\mathrm{cmol} / \mathrm{kg}) \\
\left(\mathrm{NH}_{4} \mathrm{Ac}\right)\end{array}$ & $\begin{array}{c}\text { Base sat. } \\
(\%)\end{array}$ & $\begin{array}{l}\text { OC } \\
(\%)\end{array}$ & $\begin{array}{c}\mathrm{H} \\
(\%)\end{array}$ & $\begin{array}{c}N \\
(\%)\end{array}$ \\
\hline \multirow[t]{3}{*}{ Kaoma } & no biochar & 5.6 & 4.6 & 2.2 & 60 & 0.14 & 4.3 & 45 & 0.3 & 0.04 & 0.00 \\
\hline & $5 \%$ wood char & 7.3 & 7.0 & 9.6 & 100 & $<0.001$ & 6.5 & 100 & 3.1 & 0.12 & 0.02 \\
\hline & $5 \%$ maize cob char & 6.7 & 6.3 & 5.0 & 82 & 0.01 & 5.8 & 64 & 3.4 & 0.17 & 0.02 \\
\hline \multirow[t]{3}{*}{ UNZA } & no biochar & 4.8 & 4.1 & 3.5 & 50 & 1.14 & 9.1 & 17 & 0.8 & 0.2 & 0.02 \\
\hline & $5 \%$ wood char & 6.7 & 6.2 & 8.0 & 97 & 0.02 & 10.5 & 68 & 3.5 & 0.43 & 0.07 \\
\hline & $5 \%$ maize cob char & 5.2 & 4.8 & 4.9 & 56 & 0.70 & 11.3 & 28 & 4.1 & 0.56 & 0.07 \\
\hline \multirow[t]{3}{*}{ Mkushi } & no biochar & 6.5 & 5.2 & 3.4 & 36 & 0.18 & 3.1 & 39 & 0.4 & 0.10 & 0.00 \\
\hline & $5 \%$ wood char & 7.2 & 6.8 & 8.1 & 100 & $<0.001$ & 8.4 & 100 & 3.2 & 0.17 & 0.02 \\
\hline & $5 \%$ maize cob char & 6.6 & 5.9 & 3.7 & 70 & 0.06 & 6.7 & 38 & 3.3 & 0.23 & 0.03 \\
\hline \multirow[t]{3}{*}{ Lusaka } & no biochar & 7.9 & 7.3 & $17.3 \pm 0.1$ & 100 & $<0.001$ & $16.6 \pm 0.5$ & 100 & 0.9 & 0.51 & 0.03 \\
\hline & $5 \%$ wood char & 7.9 & 7.5 & $22.8 \pm 0.3$ & 100 & $<0.001$ & $22.8 \pm 0.9$ & 100 & 3.8 & 0.62 & 0.06 \\
\hline & $5 \%$ maize cob char & 7.7 & 7.4 & $18.6 \pm 0.2$ & 100 & $<0.001$ & $19.4 \pm 0.4$ & 100 & 4.1 & 0.65 & 0.06 \\
\hline \multirow[t]{3}{*}{ Shimabala } & no biochar & 5.8 & 5.6 & $21.5 \pm 0.2$ & 100 & $<0.001$ & $26.2 \pm 1.1$ & 100 & 1.6 & 0.82 & 0.08 \\
\hline & $5 \%$ wood char & 7.0 & 6.7 & $23.7 \pm 0.7$ & 100 & $<0.001$ & $28.5 \pm 0.6$ & 100 & 4.4 & 0.96 & 0.11 \\
\hline & $5 \%$ maize cob char & 6.3 & 6.1 & $27.5 \pm 0.1$ & 100 & $<0.001$ & $28.1 \pm 0.3$ & 100 & 5.1 & 1.00 & 0.12 \\
\hline
\end{tabular}


Plant-available water. The pF-curves and plant-available water of Kaoma, Shimabala and Mkushi soils with and without 5\% maize cob biochar are presented in Figure 2 (these measurements were not performed for wood biochar). The sandy soil from Kaoma (87.9\% sand; Table 3) exhibited the lowest fraction of plant-available water $(17 \% \pm 2 \%)$, and the clay soil from Shimabala (46.2\% clay) the highest $(22 \% \pm 3 \%)$ (Figure 3). The plant-available water was significantly higher $(p<0.05)$ for Shimabala (22\%) than for Kaoma and Mkushi (17\%), but the difference was not large. The main reason for the difference in plant available water is that so much water in the Shimabala soil is present above the permanent wilting point (around 20\%). Field capacity at $\mathrm{pF}=2$ increased in the order Kaoma $<$ Mkushi $<$ Shimabala (significant difference; $p<0.05$; Figure 4).

Figure 2. Soil moisture retention ( $\mathrm{pF}$ curves) of soils without biochar (blue) and with 5\% biochar (red) (Shimabala, Kaoma, Mkushi as examples), plant available water is between pF 2 (field capacity) and pF 4.2 (wilting point). FC is field capacity, PWP is permanent wilting point. Error bars represent standard deviations of triplicate measurements.
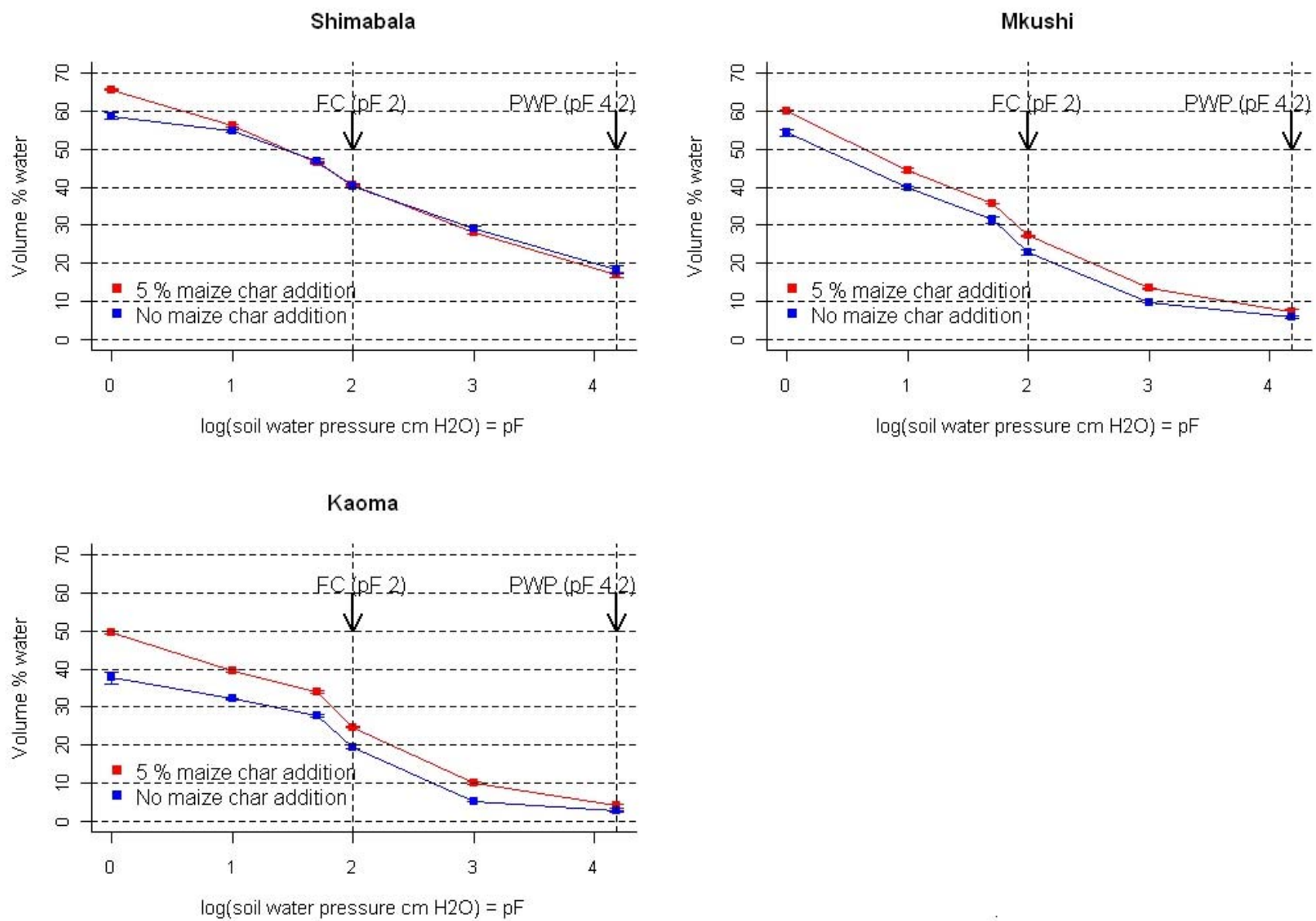
Figure 3. Plant-available water with (red bars) and without (blue bars) $5 \%$ maize cob biochar, for the five soils in hand-packed cylinders with mixed-in biochar. Plant-available water was determined as the difference in water content between $\mathrm{pF}=2$ and $\mathrm{pF}=4.2$.

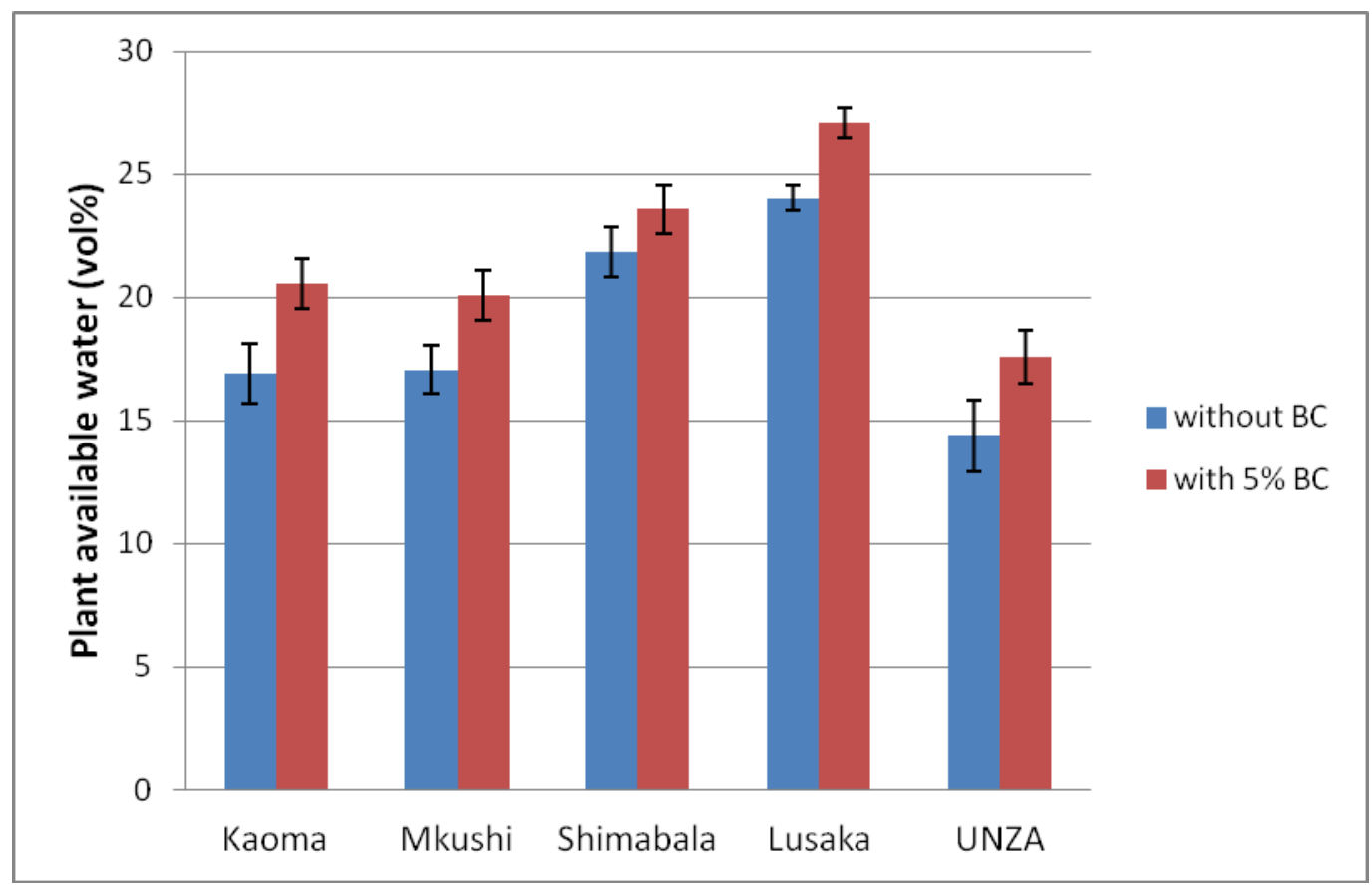

Figure 4. Field capacity $(\mathrm{pF}=2)$ with (red bars) and without (blue bars) 5\% maize cob biochar, for the five soils in hand-packed cylinders with mixed-in biochar.

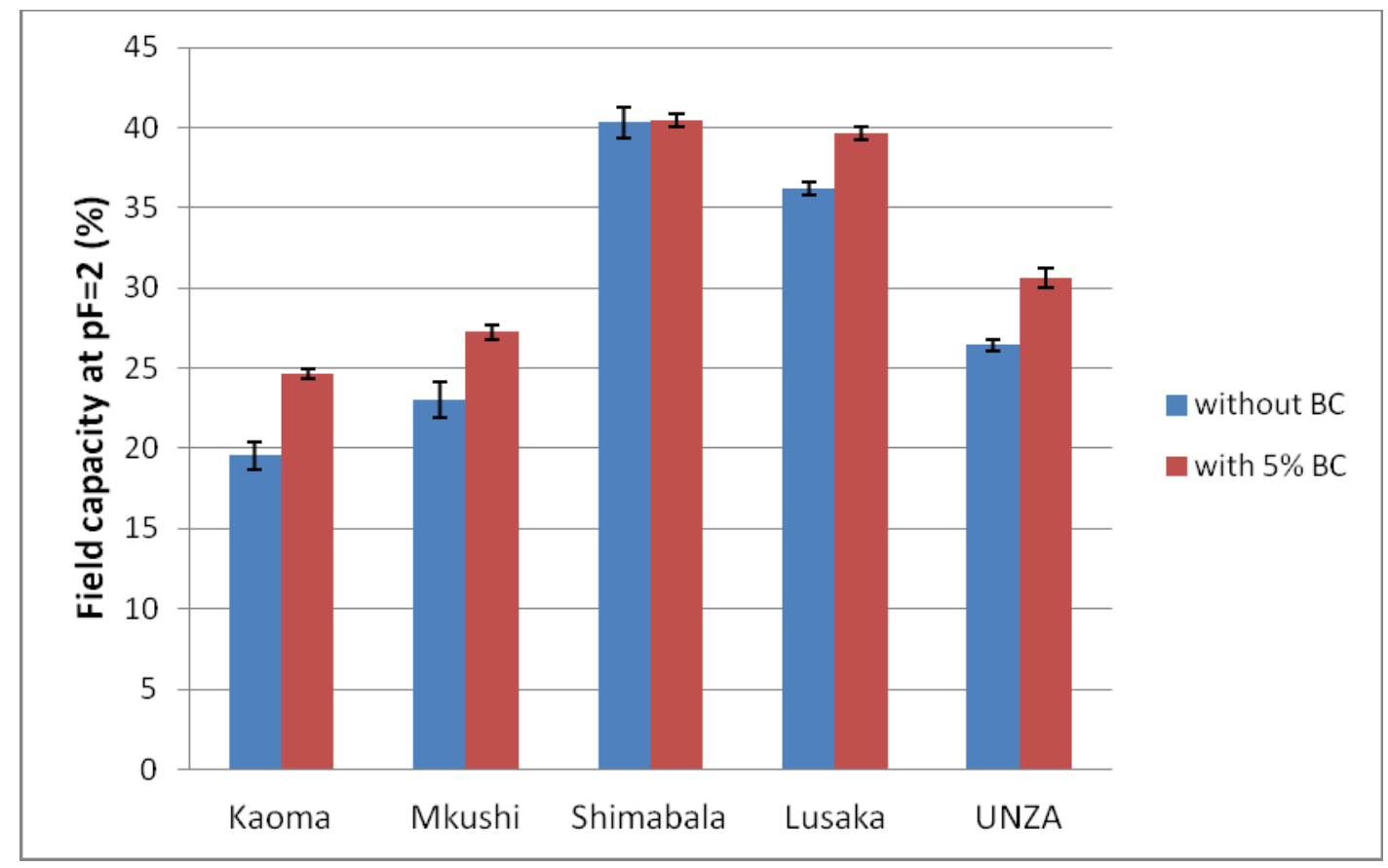


Biochar amendment (5\%) was observed to significantly increase plant-available water of all three soils tested $(p<0.05)$. The relative increase was largest for Kaoma (from 17\% to $21 \%$ ) and smallest for Shimabala (from $22 \%$ to $24 \%$ ). Field capacity was significantly increased for Kaoma and Mongu $(p<0.05)$ but not for Shimabala $(p>0.05$; Figure 4 increase in plant-available water by biochar addition is in accordance with earlier observations [4,13].

Binding of water vapor by the biochars. In Figure 5, the uptake of water vapor by the biochars, uncharred maize cobs and cellulose is plotted as a function of relative humidity (relative water pressure $\mathrm{p} / \mathrm{p}_{0}$ ). The main observation was that the water vapor sorption of unpyrolyzed cellulose was comparable to that of the biochars. Even though this time-consuming measurement ( $10 \mathrm{~d}$ for one single sample) was only done on single samples, earlier QA work in our laboratory on triplicate acidic soil samples indicated that the relative standard errors in such measurements were small (below $5 \%$ of the values, i.e. below $5 \mathrm{mg} / \mathrm{g}$ at $50 \%$ relative humidity [29]) Significant water vapor sorption probably implies less evaporation of water under dry conditions such as during the dry spells that mainly occur for the sandy soil at Kaoma. The water vapor sorption of the biochars and the feedstock (both the maize cobs and the cellulose) were similar.

Figure 5. Water uptake of the two biochars used, wood biochar and maize cob biochar, as well as of the uncharred feedstock (maize cobs) and the main constituent of the uncharred feedstock, cellulose.

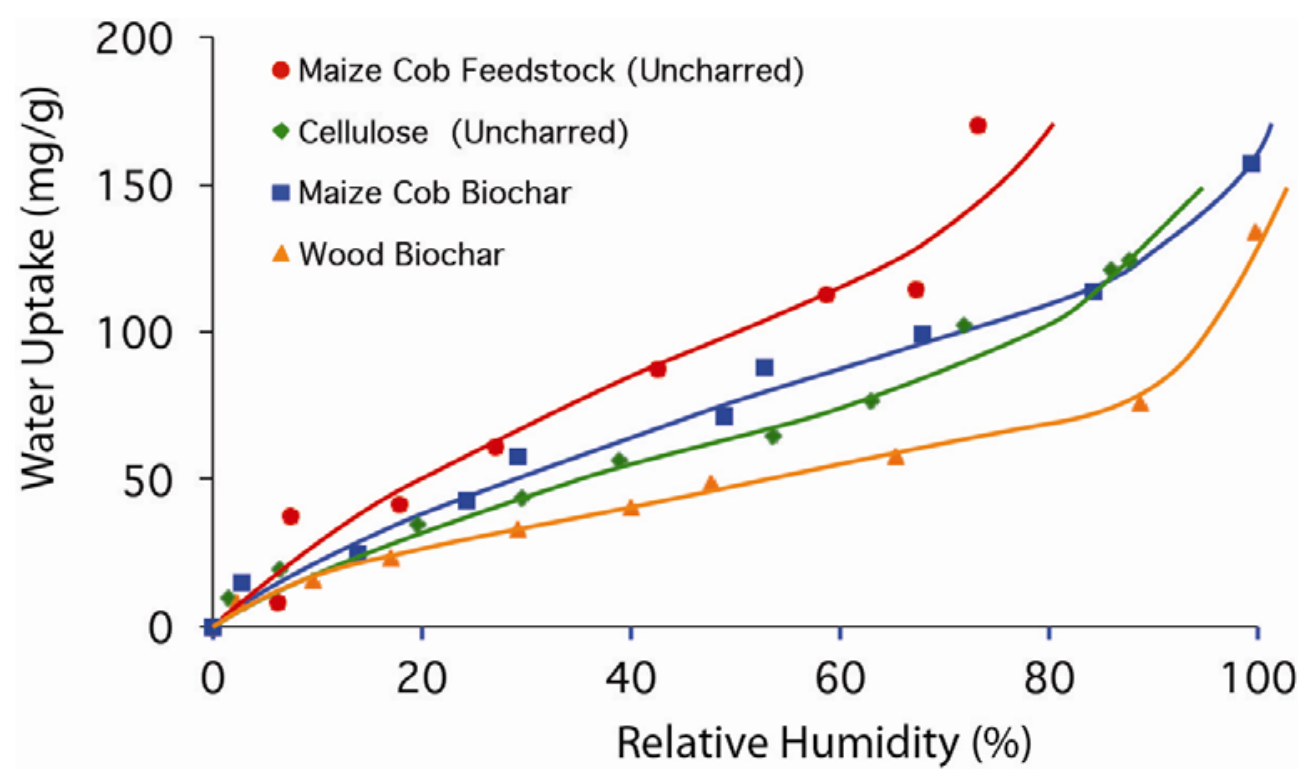

\section{Discussion}

Maize yields of the non-biochar-amended fertilized control plots varied from $<1$ to 9 tons/ha (Table 2). This reflects the strong variation in fertility of the soils tested. The yield increase in Kaoma and UNZA with only fertilizer is modest (50\% to $100 \%$ ), possibly because fertilizer is leached to the subsoil relatively quickly in these low-CEC soils.

Biochar and CF. Kaoma site - strong effect of biochar. To the best of our knowledge, the observed tripling to quadrupling of harvest yield at biochar dosages as low as 4 tons/ha is the strongest effect of biochar on maize yield reported thus far. For rice and sorghum, yield increases of up to a factor of 
eight were earlier observed at dosages of 11 tons/ha [18]. The currently observed strong effect of biochar at only 4 tons/ha is likely caused by the CF method used, which concentrates the biochar application to where most of the plant roots are. Thus, the dosage of 4 tons/ha was roughly equivalent to approximately 30 tons/ha when applied evenly to the entire field (as would be carried out in a broadcast method). In addition, the soils in Kaoma are acidic and sandy, and benefit the most from the presence of biochar.

Because of the low control yield at this site, biochar resulted in high relative yield increases, whereas the absolute increases in yield were more modest ( 2 to 3 tons/ha). The observation of highest relative effect of biochar for the lowest-fertility soils is in line with the results of a meta-analysis on the effect of fertilizers on crop yield [5] and with a study on rice growth in South-East Asia [17]. This analysis also showed the highest relative increases upon fertilizer addition for sites with the lowest non-fertilized (control) yields, with fertilizer addition giving yields up to $3000 \%$ of those for non-fertilized plots in cases where control yields were close to zero [30].

Other sites. We stress that these results should be interpreted with caution since the farmer-led trials did not allow for proper replication in block-type trials at the Lusaka and Shimabala sites. However, block trials with sufficient replication were executed for the UNZA site, and for the Kaoma and Mkushi sites statistical comparisons could be made by averaging the results from two cropping seasons.

Physical and chemical effects of biochar. Kaoma site-strong effect of biochar. The strong effect of modest biochar amendments of 4 tons/ha on maize yield in the coarse Kaoma sand is probably not explained by a $\mathrm{pH}$ effect, since available $\mathrm{Al}^{3+}$ is low even without biochar and $\mathrm{Ca}^{2+}: \mathrm{Al}^{3+}$ ratios are high (around 4) irrespective of biochar addition. Biochar significantly increased both CEC and water holding capacity ( $p<0.05$; Figure 3 ). The increase in CEC was almost twice as strong for the wood biochar as for the maize cob biochar (Table 4). The opposite trend was observed for the water vapor sorption that was stronger for the maize cob biochar than for the wood biochar (Figure 5). Yields in Kaoma were slightly more strongly increased by maize cob biochar than by wood biochar in both growth seasons, although this was not significant ( $p=0.3$; Table S1 and Figure S5). Thus this only very tentatively suggests that the increase in plant-available water (preventing leaching of water to the subsoil) and the water vapor sorption (preventing water evaporation) of biochar were the most important factors in explaining the strong yield increase in Kaoma, along with nutrient retention (increase in CEC). In the Kaoma soils these factors were apparently more important than the reduction of $\mathrm{Al}^{3+}$ availability, although a direct effect of increased $\mathrm{pH}$ (Table 4) cannot be ruled out.

Shimabala and Lusaka. The lack of biochar effectiveness in Shimabala (silty clay) and Lusaka (clay loam) is probably explained by the limited effect that the biochars had on the already favorable soil pH, CEC (Table 4), and plant-available water (Figures 2-4).

Mkushi. The lack of an effect of biochar in the Mkushi sandy clay loam is more difficult to explain, since biochar increased both $\mathrm{pH}$ and CEC of this soil. Apparently, even when $\mathrm{pH}$ and CEC are increased by the addition of biochar, this does not necessarily lead to a positive response of crop yield. Usually low soil $\mathrm{pH}$ in agriculture is associated with elevated levels of available $\mathrm{Al}^{3+}$ ( $\mathrm{Al}$ toxicity) [31], which can be expressed through the $\mathrm{Ca}^{2+} / \mathrm{Al}^{3+}$ ratio. In the case of Mkushi this parameter provides some information related to understanding the lack of an effect of biochar, as available $\mathrm{Al}^{3+}$ 
without biochar was low, and the $\mathrm{Ca}^{2+}: \mathrm{Al}^{3+}$ ratio high (above four) in both the absence and presence of $5 \%$ biochar (Table 4).

UNZA soil. In contrast to the Mkushi soil, biochar amendment increased the $\mathrm{Ca}^{2+}: \mathrm{Al}^{3+}$ ratio from $\sim 1$ to 4 (maize cob biochar) to $>100$ (wood biochar) for the UNZA sandy clay loam soil, possibly explaining (part of) the (non-significant) $30 \%-40 \%$ increase in harvest yield observed for this site.

It is not expected that the added $\mathrm{P}$ obtained via the biochar amendment was a factor of significance. In a parallel study, the presently used maize cob biochar was observed to release $204 \pm 135 \mathrm{mg} / \mathrm{kg} \mathrm{P}$ that desorbed over a period of a few days, as shown by desorption curves [32]. This amount of $\mathrm{P}$ corresponds to around $1 \mathrm{~kg} / \mathrm{ha}$ of $\mathrm{P}$ at a biochar dosage of 4 tons/ha. This is lower than the $28 \mathrm{~kg} / \mathrm{ha}$ added through the use of fertilizer (Kaoma), so unless the $\mathrm{P}$ released from the biochar is much more available than that in the synthetic fertilizer, the $\mathrm{P}$ release from the biochar itself probably cannot explain the yield increases.

\section{Conclusions}

This study in farmer-led field pilots demonstrated that a low dosage of 4 tons/ha biochar in combination with CF can have a strong effect on maize yield, in sandy, acidic soils where physical and chemical soil characteristics are improved by the amendment of biochar (see below), and owing to the nature of $\mathrm{CF}$ where the biochar is concentrated in the basins close to the plant roots. Moderately positive, but not significant, effects of biochar were observed (30\%-40\% yield increase) in a sandy clay loam soil (UNZA farm). However, in the other three soils studied, no effects on crop yield were observed, due to either the low dosage or the relatively high native fertility of the non-amended soil. The strong effect of biochar in the Kaoma sand may be tentatively explained by a combination of increased nutrient retention (probably $\mathrm{NH}_{4}^{+}, \mathrm{Mg}^{2+}, \mathrm{Ca}^{2+}, \mathrm{K}^{+}$, not P) and increased plant-available water. The moderate effect of biochar on crop yield in the UNZA soil was tentatively explained by increased nutrient retention in combination with increased $\mathrm{Ca}^{2+}: \mathrm{Al}^{3+}$ ratios. It is expected that biochar may be particularly appropriate in sandy soils with low water holding capacity found in arid regions in the world, such as in Kaoma, which are prone to drought periods during the growing season.

In the present study, one biochar from maize cobs (an agricultural waste material) was used, along with a wood biochar. Field observations showed that the use of biochar in combination with $\mathrm{CF}$ practices motivated farmers to generate their own material. The use of wood biochar would require additional wood and puts extra pressure on often limited forest resources, thus decreasing carbon stores in woodlands. Therefore, the use of agricultural waste materials (here maize cobs) as sole biochar feedstocks is recommended in future trials. The main agricultural waste material in the Zambian CF context is maize cobs, since the rest of the maize biomass is retained for soil erosion protection $[25,26]$. In the present study, wood biochar was used merely to provide a comparison in agronomic effectiveness, and its use should not be advocated in order to avoid potential deforestation caused by using such materials to produce biochar to increase soil fertility.

Further study on the coupling of biochar amendment and the concept of CF is warranted. Evaluation is needed to ascertain which soil types give the most significant crop responses. In addition, more crops should be investigated in the combined CF-biochar context. Lastly, optimal 
biochar dosages and feedstock, as well as optimal fertilizer rates need to be identified for a variety of soil types.

\section{Acknowledgements}

This study would have been impossible without the enormous effort made by the Conservation Farming Unit in Zambia (Peter Aagaard, Gibson Simusokwe, Oliver Bulaya, Kalves Wilima, Mathews Chewe, Jeremy Selby, Cacious Mubita, Sinabu Mwiya, Collins Nkatiko). The Norwegian Agency for Development Cooperation (NORAD) along with the Royal Norwegian Embassy in Zambia (Jan-Erik Studsrød and Odd E. Arnesen) are ackowledged for their financial and practical support. The Norwegian Research Council funded parts of the study through a FriPro personal stipend to GC (Norwegian Research Council project number 217918). Conservation farmers Kangayi Kapoba (Kaoma), Elleman Mumba (Shimabala) and Bruce Silanda (Mkushi) are thanked for their constructive cooperation. Magdalena Rygalska (UMB) contributed with technical assistance. Charley Kelly (USGS), Colleen E. Rostad (USGS) and David Werner (Newcastle University) provided useful comments on the manuscript. Lastly, GC thanks the Lehmann biochar group at Cornell University (in particular Johannes Lehmann, Dorisel Torres, Steven John Vanek, Dominic Woolf, Lydiah Gatere, Dawit Salomon, David Bluhm and Thea Whitman) for fruitful discussions during the preparation of this manuscript.

\section{References}

1. Lehmann, J. A handful of carbon. Nature 2007, 447, 143-144.

2. Beesley, L.; Moreno-Jimenez, E.; Gomez-Eyles, J.L.; Harris, E.; Robinson, B.; Sizmur, T. A review of biochar's potential role in the remediation, revegetation and restoration of contaminated soils. Environ. Pollut. 2011, 159, 3269-3282.

3. Woolf, D.; Amonette, J.E.; Street-Perrott, F.A.; Lehmann, J.; Joseph, S. Sustainable biochar to mitigate global climate change. Nat. Commun. 2010, 1, 1-9.

4. Glaser, B.; Lehmann, J.; Zech, W. Ameliorating physical and chemical properties of highly weathered soils in the tropics with charcoal—A review. Biol. Fertil. Soils 2002, 35, 219-230.

5. Jeffery, S.; Verheijen, F.G.A.; van der Velde, M.; Bastos, A.C. A quantitative review of the effects of biochar application to soils on crop productivity using meta-analysis. Agric. Ecosyst. Environ. 2011, 144, 175-187.

6. Lehmann, J.; da Silva, J.P.; Steiner, C.; Nehls, T.; Zech, W.; Glaser, B. Nutrient availability and leaching in an archaeological anthrosol and a ferralsol of the central amazon basin: Fertilizer, manure and charcoal amendments. Plant Soil 2003, 249, 343-357.

7. Asai, H.; Samson, B.K.; Stephan, H.M.; Songyikhangsuthor, K.; Homma, K.; Kiyono, Y.; Inoue, Y.; Shiraiwa, T.; Horie, T. Biochar amendment techniques for upland rice production in northern laos 1. Soil physical properties, leaf spad and grain yield. Field Crop. Res. 2009, 111, $81-84$.

8. Hossain, M.K.; Strezov, V.; Yin Chan, K.; Nelson, P.F. Agronomic properties of wastewater sludge biochar and bioavailability of metals in production of cherry tomato (Lycopersicon esculentum). Chemosphere 2010, 78, 1167-1171. 
9. Major, J.; Rondon, M.; Molina, D.; Riha, S.; Lehmann, J. Maize yield and nutrition during 4 years after biochar application to a colombian savanna oxisol. Plant Soil 2010, 333, 117-128.

10. Steiner, C.; Glaser, B.; Teixeira, W.G.; Lehmann, J.; Blum, W.E.H.; Zech, W. Nitrogen retention and plant uptake on a highly weathered central amazonian ferralsol amended with compost and charcoal. J. Plant Nutr. Soil Sci. 2008, 171, 893-899.

11. Yamato, M.; Okimori, Y.; Wibowo, I.F.; Anshori, S.; Ogawa, M. Effects of the application of charred bark of acacia mangium on the yield of maize, cowpea and peanut, and soil chemical properties in south sumatra, indonesia. Soil Sci. Plant Nutr. 2006, 52, 489-495.

12. Chidumayo, E.N. Effects of wood carbonization on soil and initial development of seedlings in miombo woodland, zambia. Forest Ecol. Manag. 1994, 70, 353-357.

13. Novak, J.M.; Busscher, W.J.; Watts, D.W.; Amonette, J.E.; Ippolito, J.A.; Lima, I.M.; Gaskin, J.; Das, K.C.; Steiner, C.; Ahmedna, M.; Rehrah, D.; Schomberg, H. Biochars impact on soil-moisture storage in an ultisol and two aridisols. Soil Sci. 2012, 177, 310-320.

14. Kimetu, J.; Lehmann, J.; Ngoze, S.; Mugendi, D.; Kinyangi, J.; Riha, S.; Verchot, L.; Recha, J.; Pell, A. Reversibility of soil productivity decline with organic matter of differing quality along a degradation gradient. Ecosystems 2008, 11, 726-739.

15. Lehmann, J.; Rillig, M.C.; Thies, J.; Masiello, C.A.; Hockaday, W.C.; Crowley, D. Biochar effects on soil biota-A review. Soil Biol. Biochem. 2011, 43, 1812-1836.

16. Warnock, D.; Lehmann, J.; Kuyper, T.; Rillig, M. Mycorrhizal responses to biochar in soilConcepts and mechanisms. Plant and Soil 2007, 300, 9-20.

17. Haefele, S.M.; Konboon, Y.; Wongboon, W.; Amarante, S.; Maarifat, A.A.; Pfeiffer, E.M.; Knoblauch, C. Effects and fate of biochar from rice residues in rice-based systems. Field Crop. Res. 2011, 121, 430-440.

18. Steiner, C.; Teixeira, W.G.; Lehmann, J.; Nehls, T.; de Macedo, J.L.V.; Blum, W.E.H.; Zech, W. Long term effects of manure, charcoal and mineral fertilization on crop production and fertility on a highly weathered central amazonian upland soil. Plant Soil 2007, 291, 275-290.

19. Chan, K.Y.; Xu, Z. Biochar: Nutrient properties and their enhancement. In Biochar for Environmental Management: Science and Technology; Joseph, S., Lehmann, J., Eds.; Earthscan: London, UK, 2009.

20. Wisnubroto, E.I.; Hedley, M.; Hina, K.; Camps-Arbestain, M. The Use of Biochar from Biosolids on Waitarere Sandy Soils: Effect on the Growth of Rye Grass. Presented at the New Zealand Biochar Research Centre Workshop Massey University, Palmerton North, New Zealand, 10-11 February 2011.

21. Bridle, T.R.; Pritchard, D. Energy and nutrient recovery from sewage sludge via pyrolysis. Water Sci. Technol. 2004, 50, 169-175.

22. Hale, S.E.; Lehmann, J.; Rutherford, D.; Zimmerman, A.R.; Bachmann, R.T.; Shitumbanuma, V.; O’Toole, A.; Sundqvist, K.L.; Arp, H.P.H.; Cornelissen, G. Quantifying the total and bioavailable polycyclic aromatic hydrocarbons and dioxins in biochars. Environ. Sci. Technol. 2012, 46, 2830-2838.

23. Hobbs, P.R.; Sayre, K.; Gupta, R. The role of conservation agriculture in sustainable agriculture. Phil. Trans. R. Soc. B 2008, 363, 543-555. 
24. Giller, K.E.; Witter, E.; Corbeels, M.; Tittonell, P. Conservation agriculture and smallholder farming in africa: The heretics view. Field Crop. Res. 2009, 114, 23-34.

25. Aagaard, P.J. The practice of conventional and conservation agriculture in east and southern Africa. Conserv. Farm. Unit Zambia June 2011, 1, 35-39.

26. Haggblade, S.; Tembo, G. Conservation Farming in Zambia; EPTD Discussion Paper 108; International Food Policy Research Institute (IFPRI): Washington, DC, USA, 2003.

27. Umar, B. Options for improving smallholder conservation agriculture in zambia. J. Agric. Sci. 2011, 3, 50-62.

28. Hill, R.L.; Horton, R.; Cruse, R.M. Tillage effects on soil water retention and pore size distribution of two mollisols. Soil Sci. Soc. Am. J. 2004, 49, 1264-1270.

29. Rutherford, D.W.; Wershaw, R.L.; Reeves, J.B., III. Development of Acid Functional Groups and Lactones during the Thermal Degradation of Wood and Wood Components; Paper for U.S. Geological Survey Scientific Investigations: Denver, CO, USA, 2008.

30. Chivenge, P.; Vanlauwe, B.; Six, J. Does the combined application of organic and mineral nutrient sources influence maize productivity? A meta-analysis. Plant Soil 2010, 342, 1-30.

31. Mulder, J.; van Breemen, N.; Eijck, H.C. Depletion of soil aluminium by acid deposition and implications for acid neutralization. Nature 1989, 337, 247-249.

32. Hale, S.E.; Alling, V.; Martinsen, V.; Mulder, J.; Cornelissen, G. The adsorption and desorption of phosphate-P, ammonium-N and nitrate-N infrom unwashed and washed biochars. Chemosphere 2013, in press.

(C) 2013 by the authors; licensee MDPI, Basel, Switzerland. This article is an open access article distributed under the terms and conditions of the Creative Commons Attribution license (http://creativecommons.org/licenses/by/3.0/). 